\title{
GENETIC AND ENVIRONMENTAL INFLUENCES ON
}

\section{AUTISM}

Salama, M. S..$^{(1)}$; Mohamed, F. E. ${ }^{(2)}$; Youssef, A. M. ${ }^{(2)}$; Kamal, M. M. ${ }^{(1)}$; Mahmoud, D. M. ${ }^{(1)}$; Abdallah,Elham, G. ${ }^{(3)}$ and Azmy, Ahlam ${ }^{(3)}$

1) Entomology Department, Faculty of Science, Ain Shams University

2) Pediatric Department, Faculty of Medicine, Ain Shams University

3) Medical Genetics center, Faculty of Medicine, Ain Shams University.

\begin{abstract}
Polymorphisms of genes encoding enzymes involved in float metabolism have long been hypothesized to be maternal risk factors for autism. In addition to genetic background, the exposure to mercury whether organic or inorganic can give rise to the symptoms of autism spectrum disorders (ASD) such as impairments in social interaction, communication difficulties and repetitive behaviors and interests.

Our objective was to investigate the association between metallothionein (MT) gene polymorphism and levels of mercury in the hair of Egyptian autistic children. Thirty-one autistic children diagnosed by DSM-IV (Diagnostic and Statistical Manual of Mental Disorders, $4^{\text {th }}$ Edition criteria) were subjected to hair mercury measurement using Atomic Absorption Spectrometry (AAS) and were compared to polymorphism of genes MT1A and MT1E matched healthy children.

The present study revealed that there was a highly significant increase in the mean hair mercury level in autistic patients than controls $(0.79 \pm 0.56) \mathrm{ppm}$ vs. $(0.13 \pm 0.08) \quad \mathrm{P}<0.001$ associated with polymorphism in MT1A (AG genotype). There was high significant difference in MT1E (GG genotype) between males and females $(\mathrm{P}<0.001)$ while in control were non significant.The results of this study highly support the increase in the mean hair mercury level in autistic children compared to controls.
\end{abstract}

Key words: Autism, Mercury, Genetics 
J. Environ. Sci.

Institute of Environmental Studies and Research - Ain Shams University

\section{INTRODUCTION}

The autism spectrum describes a range of conditions classified as neuro development disorders in the fifth revision of the American Psychiatric Association's Diagnostic and Statistical Manual of Mental Disorders $5^{\text {th }}$ edition (DSM-5). These disorders are characterized by social deficits and communication difficulties, stereotyped or repetitive behaviors and interests, sensory issues, and in some cases cognitive delays. (American Psychiatric Publishing, 2013).

While genetic factors are clearly important, as indicated by high concordance rates among twins and siblings, they alone cannot account for an epidemic that developed in the relatively short period of 10-20 years (Hebert and Russo, 2006). Thus environmental factors are very likely to account for the major portion of the increased prevalence of autism. Exposure to xenobiotics is an inevitable feature of contemporary life driven by an ever increasing number of threatening chemicals found in air, water and food supplies and other materials we come in contact with during our daily routine (Death et al., 2008). Mercury is a well-known neurotoxin. There are three kinds of mercury exposure: elemental mercury, as well as poisoning inorganic and organic mercury which are the most toxic forms (Chany et al., 2007). More over it is possible that individual vulnerability to toxic environmental exposure varies according to additive and interactive effects of multiple genetics, and poly morphisms that negatively affect detoxification capacity (Lichtens et al., 2010). Because the risk of developmental toxicity with low dose environmental chemicals is likely to be influenced by individual genetic 
determination of susceptibility (Gurney and Isere, 2013), it was of interest to evaluate autistic children for the frequency of polymorphic variants that affect the tissue distribution and toxicity of mercury (Bernard et al., 2002;Blanchard et al., 2006 and Windham et al., 2006).

\section{AIM OF WORK}

To investigate the association between metallothionein gene polymorphism and levels of mercury in the hair of Egyptian autistic children.

\section{SUBJECTS AND METHODS}

Subjects: This is a case-control study conducted on 31 autistic children who were diagnosed by DSM-IV criteria (Diagnostic and Statistical Manual of Mental Disorders Ver.4) following up at Child and Adolescent Psychiatry Clinic at Children Hospital, Faculty of Medicine, Ain Shams University. They were 22 males and 9 females, their ages ranged from 2 to 11 years and their mean age $( \pm \mathrm{SD})$ was $(4.73 \pm 2.008)$. The control group included 30 healthy children, 22 males and 8 females, their mean age $( \pm \mathrm{SD})$ was (5.05 \pm 2.9$)$. They were subjected to the following:

1- Full detailed history (Age, Sex .etc)

2- Psychiatric evaluation

a) IQ assessment (Intelligence Quotient) using Stanford Benet Intelligence Scale (2006).

Range of $I Q$ :

20-30 severe mental retardation

31-49 moderate mental retardation

50-70 mild mental retardation 
71-89 below average

90-109 normal IQ

110-125 above average

b) Assessment of severity of autistic symptoms using Childhood Autism Rating Scale (CARS) (Schoplek et al., 1994).

3- Recording of the history of environmental exposure to mercury.

\section{Methods:}

\section{1-Measurment of mercury levels in the hair of the children:}

A) Hair specimen collection: Hair samples were collected from cases and control by single cutting from the occipital region. The samples were cut to lengths of about 1.5-2 cm using clean stainless steel scissors. Approximately 100 strands of hair $(50 \mathrm{mg})$ were used for hair analysis assay. Adhesive paper was placed over the end of the hair strands closest to the scalp. The paper was marked with an arrow indicating the end of hair closest to the scalp. The samples were placed in a sealed plastic bag (McDowell et al., 2004)

B) Hair Hg Analysis: This was done in our study using Atomic Absorption Spectrophotometry (AAS)/hydride system which are one of the most sensitive analytical techniques used for trace element determination.

The determination depends on the formation of atomic mercury at room temperature after reacting with strong reducing agent as stannous chloride $\mathrm{SnCl}_{2}$ or sodium borohydride is used to liberate $\mathrm{Hg}$ as follows:

$\mathrm{Hg}^{2+}+\mathrm{SnCl}_{2} \rightarrow\left(\mathrm{Sncl}_{2}\right)^{+2}+\mathrm{Hg}$

C) Mercury Reduction: All mercury must be in ionic form, most is present in organic-mercury complexes. 
Mercury solutions are unstable, $0.01 \% \mathrm{k}_{2} \mathrm{Cr}_{2} \mathrm{O}_{7}$ in $0.8 \mathrm{~m} \mathrm{HNO}_{3}$ is used to prevent mercury loss.

D) Sample Preparation: The samples were cleaned by acetone three times then washed by ultra pure water and dried in an oven at $70^{\circ} \mathrm{C}$ overnight. The hair samples were then digested for $15 \mathrm{~min}$ by adding $4 \mathrm{ml}$ of $\mathrm{HNO}_{3}$ and $2 \mathrm{ml}$ of $\mathrm{H}_{2} \mathrm{O}_{2}$ to $0.1 \mathrm{~g}$ hair. The digested samples were introduced to Hydride system AAS for mercury analysis (Chakraborty, et al., 1996)

E) Genotyping: Genomic DNA purification used for PCR amplification was extracted from the whole blood sample using a DNA extraction minikit \# k0781 thermoscientific.com/onebio made in (Eu)) Lithuania kits.

MT1A and MT1E analysis were performed using PCR primers from Jilin University (as a Research Center for Genomic Medicine)

Medical Research Center, Faculty. F Medicine Ain Shams University, Cairo, Egypt.

The Primers for amplification of MT1A gene and control are

F-5' ACTAAGTGTCCTCTGGGGCTG-3'

\section{R-5' AATGGGTCACGGTT6TATGG-3'}

and the other primers for amplification of MT1E gene and control are F-5'-TCCTCTGGGTCTGGGTTCT-3'

\section{R-5'-GCAATGGCTCAGTGTTGTAT-3'}

PCR Amplification was performed in $25 \mu 1$ reaction mixture with each primer set for which the conditions included on initial denaturation at $94^{\circ} \mathrm{C}$ for $5 \mathrm{~min}$ followed by35-40 cycles of $94^{\circ} \mathrm{C}$ for $45 \mathrm{Sec}, 55^{\circ} \mathrm{C}$ for $1 \mathrm{~min}$ And $72^{\circ}$ $\mathrm{C}$ for $1 \mathrm{~min}$ and $\mathrm{A}$ final elongation at $72^{\circ} \mathrm{C}$ for $10 \mathrm{~min} .15 \mu \mathrm{l}$ of PCR products was completely digested with 10 units of restriction enzymes, enzyme A fast 
digest Pst1 \#fd0614 and enzyme $E$ fast digest Nde1\#fd0583 (thermoscientific), according to Lina Y. et al., 2008.

Statistical Analysis: Results were analyzed using the Statistical Package of Social Science (SPSS)Computer Software program version 21.0 (Chicago IL, USA), Data were presented in the form of frequencies and percentages. Differences among groups were tested using Pearson's chi-square test.P value of 0.05 indicates significant results, while $\mathrm{P}$ value of $<0.001$ indicates highly significant results.

\section{RESULTS}

There was a highly significant increase in the level of mean hair mercury in patients $(0.79 \pm 0.56 \mathrm{PPm}) \mathrm{P}<0.001$ compared to control group $(0.127 \pm$ $0.08 \mathrm{ppm}$ ) (Table 1), While there was no significant difference regarding IQ and also CARS score (Table 2).

Table (1) shows also the high significant difference between male patients and control $(\mathrm{P}<0.001)$ and between female patients and control $(\mathrm{P}<0.001)$.

In MT1A, AG genotype was higher in patients than control $(\mathrm{P}<0.001)$ (Table 3). The results in Table (5) shows that GG genotype in MT1E is higher in patients than control group. Results also show that allele $\mathrm{T}(\mathrm{P}<0.05)$ and allele $\mathrm{G}(\mathrm{p}<0.001)$ were also higher in patients than control group (Table 5).There was no significant association between MT1A and MT1E genotyping with mercury levels (Tables $4 \& 6$ ) 
Regarding SNP selection and RFLP analysis, we detected 2 SNPs using PCR - RFLP analysis based on the SNP map of MT1A and MT1E genes.

Table (1): Comparison between mercury levels in autistic patients and controls

\begin{tabular}{|l|c|c|c|}
\hline $\begin{array}{c}\text { Mercury level } \\
\text { Mean } \pm \text { SD }\end{array}$ & $\begin{array}{c}\text { Control } \\
(\mathbf{p p m})\end{array}$ & $\begin{array}{c}\text { Patients } \\
(\mathbf{p p m})\end{array}$ & p-value \\
\hline \hline Total & $0.127 \pm 0.08$ & $0.79 \pm 0.56$ & $\mathrm{P}<0.001 * *$ \\
\hline Male & $0.13 \pm 0.08$ & $0.9 \pm 0.48$ & $\mathrm{P}<0.001^{* *}$ \\
\hline Female & $0.11 \pm 0.06$ & $0.53 \pm 0.63$ & $\mathrm{P}<0.001 * *$ \\
\hline
\end{tabular}

** High significant difference

Table (2): Statistical comparison between different groups of cases according to their IQ and CARS regarding to mercury levels

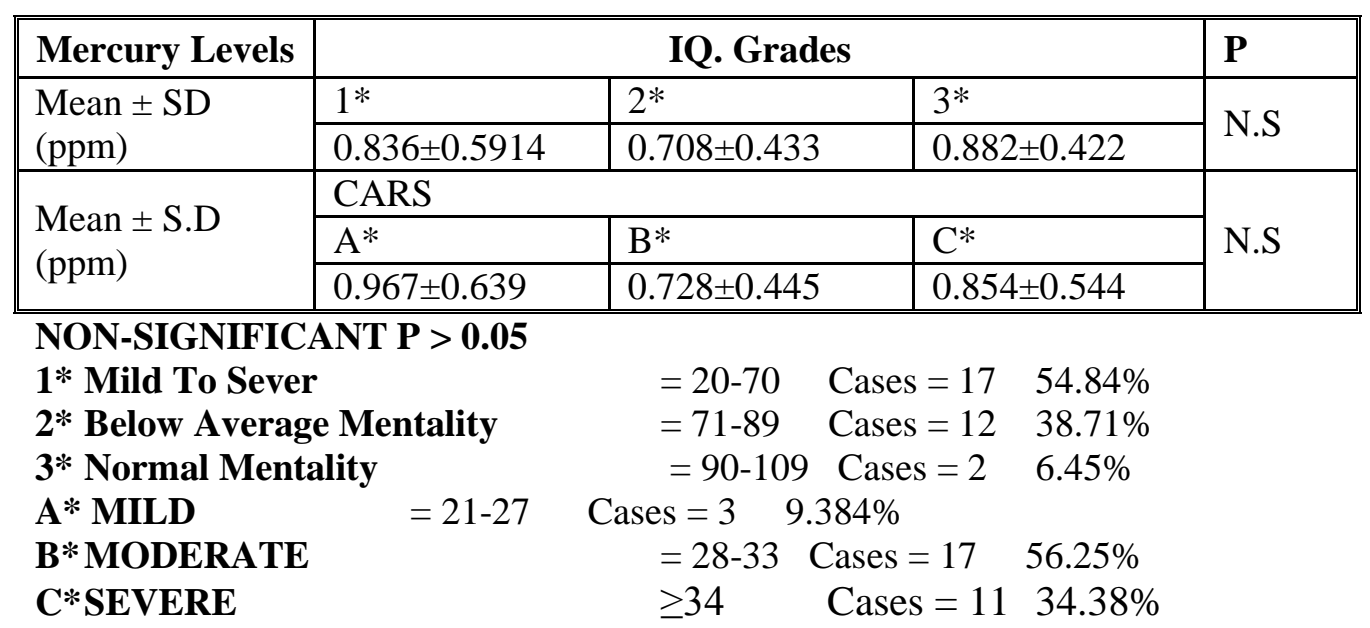


J. Environ. Sci.

Institute of Environmental Studies and Research - Ain Shams University

Table (3): Comparison between MT1A genotypes, alleles among autistic patients and controls

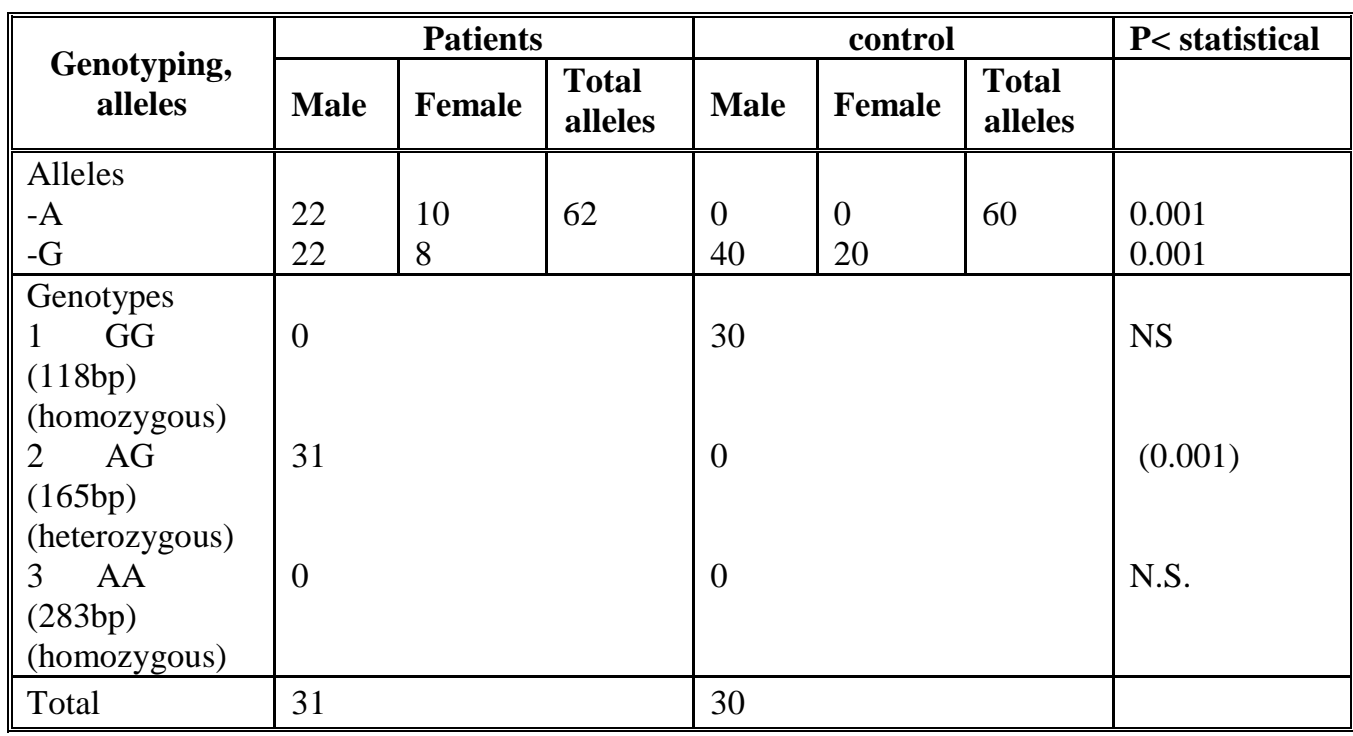

Table (4): Comparison between mercury levels in different MT1A genotypes, alleles among autistic patients and controls

\begin{tabular}{|c|c|c|c|c|c|c|c|c|}
\hline \multirow[b]{2}{*}{$\begin{array}{c}\text { Genotyping, } \\
\text { alleles }\end{array}$} & \multicolumn{3}{|c|}{ Patients } & \multicolumn{3}{|c|}{ Control } & \multirow{2}{*}{$\begin{array}{c}\text { Mercury } \\
\text { level } \\
\text { Mean } \\
\pm \text { S.D } \\
\text { (ppm) }\end{array}$} & \multirow[b]{2}{*}{ P-value } \\
\hline & Male & $\begin{array}{c}\text { Femal } \\
\mathrm{e}\end{array}$ & $\begin{array}{l}\text { Total } \\
\text { alleles }\end{array}$ & Male & Female & $\begin{array}{l}\text { Total } \\
\text { alleles }\end{array}$ & & \\
\hline Alleles & $\begin{array}{l}22 \\
22\end{array}$ & $\begin{array}{l}10 \\
8\end{array}$ & 62 & $\begin{array}{l}0 \\
40\end{array}$ & $\begin{array}{l}0 \\
20\end{array}$ & 60 & $\begin{array}{l}0.181 \pm \\
0.55 \\
0.77 \pm \\
0.57 \\
\end{array}$ & $\begin{array}{l}\mathrm{NS} \\
\mathrm{p}>0.05\end{array}$ \\
\hline $\begin{array}{l}\text { Genotypes } \\
1 \text { GG } \\
\text { (homozygous) } \\
2 \text { AG } \\
\text { (heterozygous) } \\
3 \text { AA } \\
\text { (homozygous) }\end{array}$ & & $\begin{array}{c}0 \\
31 \\
0\end{array}$ & & & $\begin{array}{l}0 \\
0\end{array}$ & & $\begin{array}{l}0.79 \pm \\
0.56 \\
0.79 \pm \\
0.56 \\
0\end{array}$ & $\begin{array}{l}\text { NS } \\
\text { N.S. } \\
0\end{array}$ \\
\hline Total & \multicolumn{3}{|c|}{31} & \multicolumn{3}{|c|}{30} & & \\
\hline
\end{tabular}


Table (5): Comparison between MT1E genotypes, alleles among autistic patients and controls

\begin{tabular}{|c|c|c|c|c|c|c|c|}
\hline \multirow{2}{*}{$\begin{array}{c}\text { Genotyping, } \\
\text { alleles }\end{array}$} & \multicolumn{3}{|c|}{ Patients } & \multicolumn{3}{|c|}{ Control } & \multirow[t]{2}{*}{$\begin{array}{c}\mathbf{P}< \\
\text { statistical } \\
\end{array}$} \\
\hline & Male & Female & $\begin{array}{l}\text { Total } \\
\text { alleles }\end{array}$ & Male & Female & $\begin{array}{c}\text { Total } \\
\text { alleles }\end{array}$ & \\
\hline $\begin{array}{l}\text { Alleles } \\
-\mathrm{T} \\
-\mathrm{G}\end{array}$ & $\begin{array}{l}4 \\
40\end{array}$ & $\begin{array}{l}2 \\
16\end{array}$ & 62 & $\begin{array}{l}18 \\
22\end{array}$ & $\begin{array}{l}10 \\
10\end{array}$ & 60 & $\begin{array}{l}P<0.001 \\
P<0.001\end{array}$ \\
\hline $\begin{array}{l}\text { Genotypes } \\
1 \quad \text { TT } \\
\text { (63bp) } \\
\text { (homozygous) }\end{array}$ & \multicolumn{2}{|c|}{$\begin{array}{c}\text { male } \\
2\end{array}$} & $\begin{array}{c}\text { Female } \\
1\end{array}$ & \multicolumn{2}{|c|}{$\begin{array}{c}\text { male } \\
0\end{array}$} & $\begin{array}{c}\text { female } \\
0\end{array}$ & NS \\
\hline $\begin{array}{l}2 \quad \text { GT } \\
\text { (216bp) } \\
\text { (heterozygous) }\end{array}$ & \multicolumn{2}{|c|}{0} & 0 & \multicolumn{2}{|c|}{18} & 10 & NS \\
\hline $\begin{array}{l}3 \text { GG } \\
\text { (279bp) } \\
\text { (homozygous) } \\
\end{array}$ & \multicolumn{2}{|c|}{20} & 8 & \multicolumn{2}{|c|}{2} & 0 & $\mathrm{P}<0.05$ \\
\hline Total & \multicolumn{3}{|c|}{31} & \multicolumn{3}{|c|}{30} & \\
\hline
\end{tabular}


Table (6): Comparison between mercury levels in different MT1E genotypes, alleles among autistic patients and controls

\begin{tabular}{|c|c|c|c|c|c|c|c|c|}
\hline \multirow{2}{*}{$\begin{array}{c}\text { Genotyping, } \\
\text { alleles }\end{array}$} & \multicolumn{3}{|c|}{ Patients } & \multicolumn{3}{|c|}{ Control } & \multirow{2}{*}{$\begin{array}{c}\text { Mercury } \\
\text { level } \\
\text { Mean } \\
\pm \text { S.D } \\
\text { (ppm) }\end{array}$} & \multirow{2}{*}{$\begin{array}{c}\text { P- } \\
\text { value }\end{array}$} \\
\hline & Male & Female & $\begin{array}{c}\text { Total } \\
\text { alleles }\end{array}$ & Male & Female & $\begin{array}{c}\text { Total } \\
\text { alleles }\end{array}$ & & \\
\hline $\begin{array}{l}\begin{array}{l}\text { Alleles } \\
-T \\
-G\end{array} \\
\text { - }\end{array}$ & $\begin{array}{l}4 \\
40\end{array}$ & $\begin{array}{l}2 \\
16\end{array}$ & 62 & $\begin{array}{l}18 \\
22\end{array}$ & 10 & 60 & $\begin{array}{l}0.181 \pm \\
0.55 \\
0.8 \pm \\
0.58\end{array}$ & $\begin{array}{l}\text { N.S. } \\
\text { N.S. }\end{array}$ \\
\hline $\begin{array}{l}\text { Genotypes } \\
1 \quad \text { TT } \\
\text { (homozygous) } \\
2 \text { GT } \\
\text { (heterozygous) } \\
3 \quad \text { GG } \\
\text { (homozygous) }\end{array}$ & $\begin{array}{r}\mathrm{Ma} \\
2\end{array}$ & & $\begin{array}{c}\text { Female } \\
1 \\
0 \\
8\end{array}$ & $\begin{array}{r}\mathrm{Mal} \\
0 \\
18\end{array}$ & & $\begin{array}{c}0 \\
0 \\
10 \\
0\end{array}$ & $\begin{array}{l}0.83 \pm \\
0.56 \\
0 \\
0.8 \pm \\
0.58 \\
\end{array}$ & $\begin{array}{l}\text { N.S. } \\
\text { N.S. } \\
\text { N.S. }\end{array}$ \\
\hline Total & \multicolumn{3}{|c|}{33} & \multicolumn{3}{|c|}{30} & & \\
\hline
\end{tabular}

Using PCR based restriction fragment length polymorphism method in two of the MT genes (MT1A and MT1E genes) and single nucleotide polymorphisms (SNPs) of those genes. Thirty one autistic children were tested for the frequency distributions of the $G$ allele. Particularly two restriction endonuclease enzymes (Pst1 and NDE1) which cut in SNPs-were used in this study. Different genotypes in both patients showed a high significant polymorphism.

Pst1 end nuclease using primer rs 8052394 cleaves the PCR product at the recognition site (rs) $5{ }^{`} \mathrm{CTGCA} \mathrm{G} 3{ }^{`}$ at fragment lengths $118 / 165 / 283$ at GG/GA/AA respectively. NDE1 endonuclease using primer rs 708274 
cleaves the PCR product at the recognition site (rs) 5'CA/TATG3' at fragment lengths 63/216/279 at TT/TG/GG respectively.

\section{DISCUSSION}

The present study was conducted on 31 autistic children (90\% of autistic children were diagnosed before the age of 3 years while the remaining $10 \%$ after the age of 3 years). Autistic group age range from 2-11 years with mean + SD average age $4.73 \pm 2.008$ years. These finding are agreement with (Gray and Tongue, 2001) who found that parents become concerned about autistic behavior at age 12-30 months.

While (Mandell et al., 2002) found that there is often wide variation in the age at which children present for diagnosis to a specialized developmental centre. One cause for these delays may be due to the lack of access to care, whether for diagnosis or to obtain necessary therapy in certain socioeconomic groups.

In the current study $70.96 \%$ Of Autistic children were male and $29.04 \%$ were female with male/female ratio 2:4. This in consistence with (Geier D.A and Geier M.R, 2007) who found that the male/female ratio of patients diagnosed with ASDs is at least 3: 1.

Also (David and Skuse, 2000) found that males were at least four times more likely to develop autism than females and among relatives with a broader autistic phenotype males are predominate.

In respect to IQ level in the present study $54.84 \%$ of autistic children were mild to severe mentally retarded, $38.7 \%$ were below average IQ level, and $6.45 \%$ had normal IQ level. 
While (Hurley and Levites, 2007) speculate that much of the recent advance in ASD has been with persons who are intellectually normal.

The current study showed an significant increased hair mercury levels among autistic group compared to controls $(\mathrm{p}<0.001)$ in agreement with (Fido and Al Soad, 2005) who reported that autistic children had a higher levels of mercury than non autistic $(\mathrm{p}<0.001)$ children.

In contrary with our results (Holmes et al., 2003) found that mercury levels in the hair of autistic children were significantly lower than non autistic controls group, they suggested that autistic children retain mercury in their body due to impairments in detoxification path ways.

In the current study there was no significant difference in mean levels hair mercury among different autistic and their IQ levels

These findings supported by the study of (Axelrod et al., 2001) who concluded that IQ does not represent all neurodevelopment deficits associated with mercury exposure.

While (Wright et al., 2006) reported that heavy metals such mercury are a particularly high concern low levels are associated with neurological impairments including lower IQ.

The present study showed that higher hair mercury levels are associated with decreased severity of the autism $0.967 \pm 0.639$ (table 2) NS $p>0.05$, these findings are in agreement with (Holmes etal,2003) who found that the lower the severity of autism the higher the levels of hair mercury. 
In the present study autistic males had a significant increase in the mean mercury level $(0.9 \pm 0.48)(\mathrm{p}<0.001)$ than that of mercury level $(0.53 \pm 0.6)$ in autistic female. Similar to our study (Yasatake et al., 2003) who reported that mercury level in the hair of males was higher than that of females.

This study also revealed that there was an association between polymorphism MT1A and Mt1E with autism by showing higher incidence when compared with the control group.

However (Yong et al., 2008) reported that MT1A does not have any association with increased susceptibility to autism among their population sample.

In the current study, there is no estimation of MT1E gene frequency alleles and mercury level in autistic children $(\mathrm{p}>0.05)$ as a risk factor of autism among Egyptian population.

As regards MT1E polymorphism, our results showed that all the patients carried the GG genotype, compared to controls. (Grarap and Andersen, 2007) study showed that $\mathrm{G}$ allele is associated with increased risk of having a child with autism.

This is in contrast to (Copped et al., 2006) who demonstrated the presence of GG genotype among their sample of patients. However, (Chany A et al., 2005) found no significant with MT1E.

\section{REFERENCES}

American psychiatric Association(2013): Diagnostic and statistical manual of mental disorders, $5^{\text {th }}$ ed. Washington, DC, USA.

American Psychiatric Publishing (2013): Autism Spectrum Disorder fact sheet, American Psychiatric Publishing, Arlington, Va, USA. 
Axelrod DA., Bellinger DC., Ryan LM and Woodruff IJ. (2001): Dose response relationship of prenatal Mercury exposure and IQ. Environ Healths Percept 115:609-615.

Bernard S, Enagati A. Roger h., Bin stock T Redwood I.(2002): The role of mercury in the pathogenesis of autism.Mol. Psychiat, 7: 542-543.

Blanchard H., and Windham A, (2006): The role of mercury in the pathogenesis of autism p6. Curropin Pediatr., 27(6): 685-691.

Chakra borty R., Dos AK., Cervera M and Dela Guardia Fresenius. (1996), Sample preparation of hair mercury. J Anal Chem 365: 99-111.

Chan CH., NgDK., and Lee RS.,(2007): Low level chronic mercury exposure children and adolescents: meta-analysis. Pediatric., 5: 80-87.

Chany O'Fallon-Emery, N-Mircher C., and B lehaut H (2005): No association between common polymorphism genes of floate and the risk of autism gene., Genet Med., 94:166-169.

Copped F., Marini G., Bargagnas., and Stappial, (2006): Floate Gene Polymorphisms and the Risk of Autism. AM.J. Med Genet, A 140: 1083-1091

Deaths R, Nuratore C., and Benz Cry j, (2008): How environmental and genetic factors combine to cause Autism: are dox/ methylation hypothesis Neuro Toxical 29:190-201.

Fido A., and Al, Soad S. (2005): Toxic I race Element in the Hair of Children with Autism., Mol. Autism, 9: 290-198.

Ganasyam S.R., Rae, T.B., martly, Y.S.R., Tyothy, A., and Suyatha M. (2012): Association of Estrogen Receptor Gene and Metallothionein, Gene polymorphism in Autism. Women of Andhra Pradesh. Indian Journal of Clinical Biochemistry. 27 (1): 69-73.

Geier DA., and Geier MR, (2007): A prospective study of levels in patients with autistic spectrum disorders, Neuro endocrino lLett. 28: 567573. 
Grarap N., and Andersen G., (2007): Gene-environment Interactions in the Pathogenesis of Autism and Metabolism. Mol. Med., 10: 420426.

Gray KM., and Tongue BJ., (2001); Are there Early Features of Autism in Infants and Preschool Children, Journal of Pediatrics and Child Health. 37:221-226.

Gurney MR., and Isere KB., (2013): Genetic and Environmental Factors in Autism; Lin. Chem. 15: 5772-53295.

Herbert MR., and Russo JP.,(2006): Yang's Autism and Environmental Genomics Neurotoxicology. J Clin Child Adolesc Psychol. 27:671-84.

Holmes AS., Blaxill MF., and Haley BE., (2003): Reduced Levels of Mercury in First Baby Haircuts of Autistic Children, International Journal of Toxicology 22: 277-285.

Hurley AD., and levities AS.,(2007): The Importance of Recognizing Autism Spectrum Disorders in Intellectual Disability. Mental Health Aspects of Developmental Disabilities 10:157-161

Lichens SP., Car Istrom E, Rastam M., Gill berg C., and Anckarsater H., (2010): The Genetics of Autism Spectrum Disorders and Related Neuropsychiatry disorders in childhood. Am J Psychiatry; 167(11): 1357-63.

Lina yang, hongyan Li, Ting Yu, Haijun Zhao, M. Georgecherian, Lu Cai, and Ya Liu.(2008): Polymorphisms in Metallothionein MT1A and MT1E Genes Associated with the Risk of Autism .Am. J. Physiol Endocrinol Metab. 294: 987-992.

Man dell DS.,ListerudJ., Levy SE., and Pinto Martin JA,(2002): Race Differences in the Age at Diagnosis Among Medicaid Eligible Children with Autism, Journal of American/Academy of Child and Adolescent Psychiatry 41:1447-1453.

Mc Dowell MA. , Dillon CF., and Osterloh J,(2004): Hair mercury levels in Us children and women of childbearing age. Environ Health Perspect 112:1165-71.

R.M. Hernadon (2006): "Stanford-binet Intelligence Scaly Pediatric Developmental Scales" in Hand Book of Neuralgic rating scales, Lancet, 3: 30-31, 
Schopler E., Reichler R.J., and Renner B.R.,(1994): The Childhood Autism Rating Scale, Western Psychological Services. Los Angeles, CA: Westron Psychological Sevices. 15: 963-972.

Wright RO, Woolf AD. (2006): Neuropsychological Correlates of Hair Mercury Manganese and Cadmium levels in School-age Children Residing Near a Hazardous waste site. Neurtoxicology. 27:210216.

Yang L.L., Zhao H., cherianm., and Liuy (2008): Polymorphisms Mellaothionein 1 and 2 Genes Associated with Autism and its Complication American Journal of Physiology Endocrinology 294(5).E:987- 992

Yasatake A., Matsumoto M., Yamagachi M., and Hachiga N., (2003): Current Hair Mercury levels in Japanese: Surrey in five districts. The Tehoku Journal of Experimental Medicine 199:161-169.

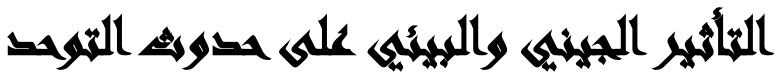

[1]

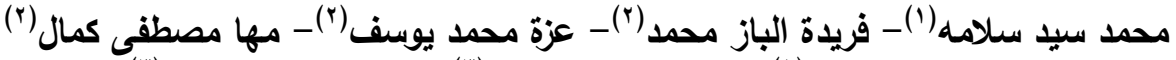

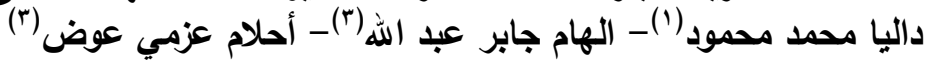

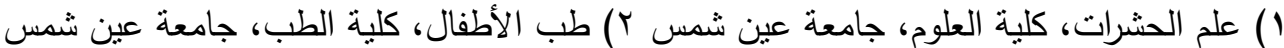

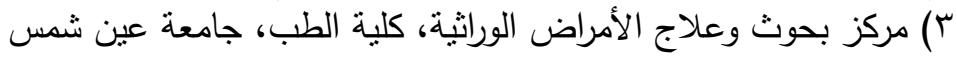

\section{المستخلي}

التعدد الجيني للأنزيمات المشاركة في التمنيل الغذائي لحمض الفوليك تعد من عوامل الخطر

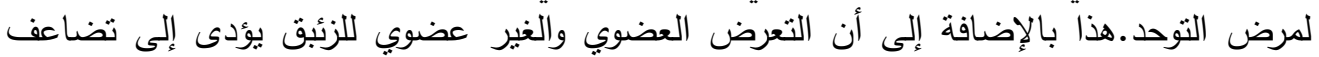

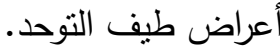

تهدف هذه الدراسة إلي التحقق فى ما إذا كان هناك ارتباط بين تعدد أنثكال جين الميتالوثيونين

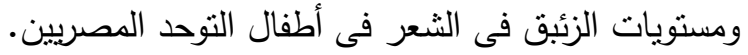

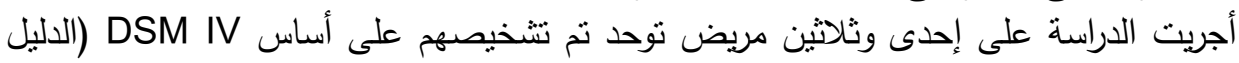
التشخيصي والإحصائي للاضطرابات العقلية). 
تم قياس نسبة الزئبق فى الثعر عن طريق استخدام جهاز مطياف الامتصاص الذئن الذرى ونم

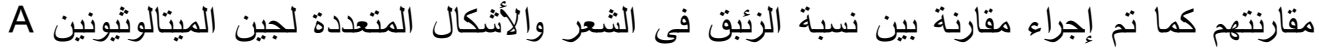

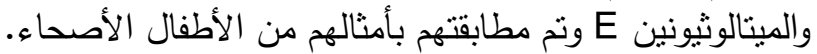

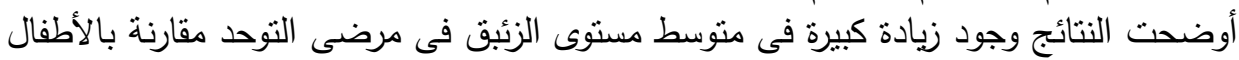

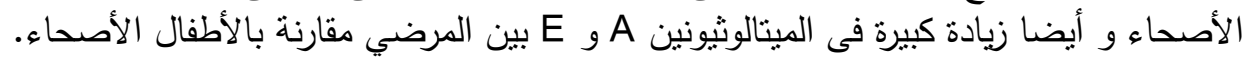

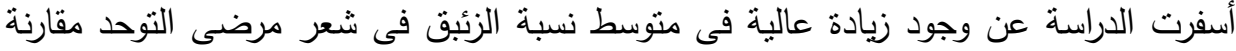

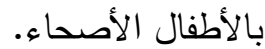

